\title{
Occurrence of a rust disease of Fuchsia caused by Pucciniastrum epilobii in Indonesia
}

\author{
Dono Wahyuno • Dewi Susan • Makoto Kakishima
}

Received: 6 February 2012 / Accepted: 15 August 2012 /Published online: 30 September 2012

(C) Australasian Plant Pathology Society Inc. 2012

\begin{abstract}
Fuchsia species (Onagraceae) have been introduced into Indonesia as ornamental plants and are cultivated in gardens and parks of mountainous areas. A rust disease was found on leaves of Fuchsia macrostemma var. globosa at Cipanas, West Java, Indonesia in February 2010. There has been no previous report on the rust disease of Fuchsia species in Indonesia. Based on morphological characteristics of the causal rust fungus it was identified as Pucciniastrum epilobii. Its occurrence and morphology are reported.
\end{abstract}

Keywords Fuchsia $\cdot$ Rust disease $\cdot$ Pucciniastrum epilobii

\section{Introduction}

Fuchsia species (Onagraceae) are perennial shrubs mostly originating from South America. About 100 species of Fuchsia are distributed world wide and most of them are planted as ornamental plants in gardens and parks or cultured in pots for decoration.

In Indonesia, Fuchsia species are mostly cultivated in subtropical hilly areas (av $1.500 \mathrm{~m}$ a.s.1.) in West Java

\section{Wahyuno $(\bowtie)$}

Indonesian Medicinal and Aromatic Crop Research Institute,

Tentara Pelajar No. 3,

Bogor 16111, Indonesia

e-mail: dwahyuno@yahoo.ca

D. Susan

Indonesian Institute of Sciences,

Cibinong,

Bogor 16911, Indonesia

M. Kakishima

Graduate School of Life and Environmental Sciences,

University of Tsukuba,

Ibaraki 305-8572, Japan
Province. A rust disease was found on Fuchsia macrostemma var. globosa for the first time at Cipanas, Indonesia in February 2010. This disease occurred in the majority of plants and caused serious damage. There is no report of rust diseases on Fuchsia species in Indonesia (Boedijn 1960; Semangun 1992).

\section{Materials and methods}

Specimens on Fuchsia macrostemma Ruiz et Pavon var. globosa Bailey were collected from two different places at Cipanas, Indonesia and kept as dry specimens in Herbarium Balittro (HBI-Bal), Indonesian Medicinal and Aromatic Crops Research Institute, Bogor, Indonesia: HBI-Bal 505 (TSH-R4333), Cibodas Botanical Garden, Cipanas, Cianjur, February 24, 2010, D. Wahyuno, M. Kakishima, Dewi and I. Hidayat; HBI-Bal 512, Gunung Putri, Cipanas, Cianjur, June 15, 2010. D. Wahyuno. The specimens were also deposited in the Mycological Herbarium at the Graduate School of Life and Environmental Sciences, University of Tsukuba, Japan (TSH). For comparative morphology specimens from TSH were used: TSH-R7203, Uredo fuchsiae Arthur et Holway on cultivated Fuchsia sp., Cardiff, Wales, England, June 2, 1932; TSH-R12804, Pucciniastrum epilobii Otth on Epilobium pyrricholophum Franch et Sav., Teshirozawa, Oku-kinu, Tochigi Prefecture, Japan, Sept 12, 1963, Sugimoto; TSH-R4285 P. epilobii on Epilobium cephalostigma Haussk, Kawakami Experimental Forest of University of Tsukuba, Minamisaku-Gun, Nagano Prefecture, Japan, July 30, 1981, Ono Y.

For microscopic observations, hand sections of sori on leaves and urediniospores collected by scraping the uredinia were mounted in a drop of lactophenol solution on glass. The sizes of sori and urediniospores were based on 30 sori and 50 spores, respectively. Germ-pore numbers and 
distribution pattern were observed by aniline blue squash technique (Jennings et al. 1989). For SEM, specimens and urediniospores were attached on specimen holders and coated with platinum-palladium with Hitachi E-1030 Ion Sputter. They were observed under SEM (Hitachi S-4200) operating at $15 \mathrm{kV}$.

\section{Results}

Symptom and sign of the disease

Discoloured or yellow spots appeared on infected leaves which were usually found on the lower or middle parts of plants. Yellow lesions sometimes expanded to cover the leaves. Necrotic spots were also observed in the center of lesions. In severely infected plants, leaves changed colour to yellow or brown and fell prematurely.
The light orange, protruding, uredinial sori were produced on lower leaf surfaces and scattered or clustered (Fig. 1a).

Morphology of rust fungus and its identification

Only the uredinial stage was observed on the lower surface of leaves in specimens of $F$. macrostemma var. globosa collected in Indonesia. These uredinia were subepidermal, $105-437 \mu \mathrm{m}$ in diameter and were covered by thin peridia which ruptured at the apex. Peridial cells were hyaline, hemispherical to irregular in shape and $13-24 \mu \mathrm{m}$ in diameter (Fig. 1b, c). Ostiolar cells at the apex of peridia were rounded and smooth (Fig. 1d). Urediniospores were pedicelate, oblong to globose, $15-23 \times 11-17 \mu \mathrm{m}$ and their germ-pores were obscure. Cell walls of urediniospores were hyaline, thin with uniform thickness, and echinulate (Fig. 1e, f; Table 1).
Fig. 1 Pucciniastrum epilobii on Fuchsia macrostemma var. globosa (HBI-Bal 505). a Uredinia on abaxial leaf surface, b Vertical section of an uredinium, $\mathbf{c}$ Vertical section of an uredinium observed by SEM, d Surface view of an uredinium observed by SEM. e Urediniospores with uniform thickness of cell walls, and f Urediniospores observed by SEM

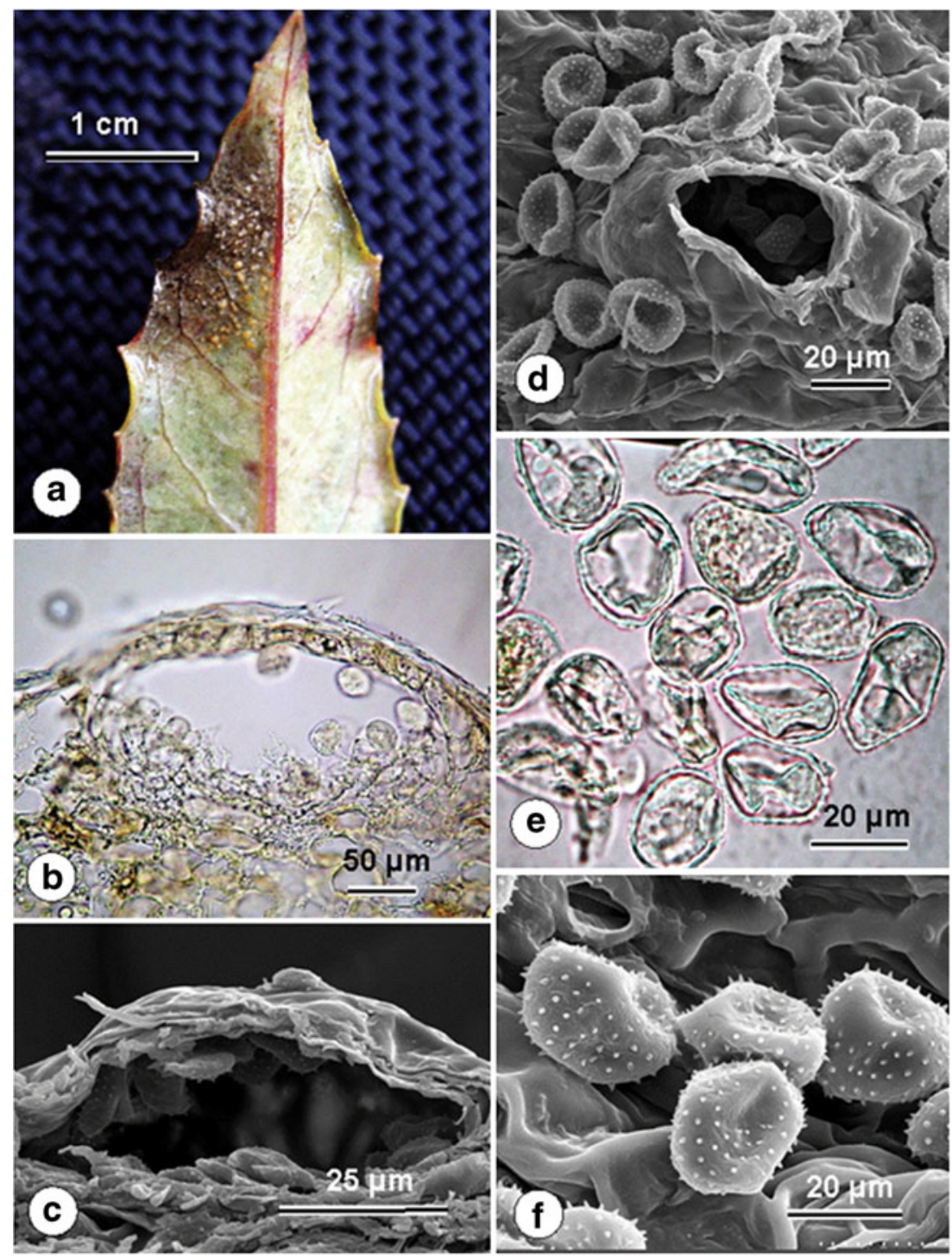


Table 1 Comparative morphology of uredinial stages among specimens

\begin{tabular}{|c|c|c|c|c|c|}
\hline Specimens & HBI-Bal $\left.505^{*}\right)$ & HBI-Bal $\left.512^{*}\right)$ & TSH-R4285 & TSH-R7203 & TSH-R12804 \\
\hline Hosts & $\begin{array}{l}\text { Fuchsia macrostemma Ruis } \\
\text { \& Pavon var. globossa }\end{array}$ & Fuchsia sp. & $\begin{array}{l}\text { Epilobium } \\
\text { cepalostigma Haussk }\end{array}$ & Fuchsia sp. & $\begin{array}{l}\text { Epilobium pyrricholophum } \\
\text { Franch. et Sav. }\end{array}$ \\
\hline Locality & Indonesia & Indonesia & Japan & England & Japan \\
\hline \multicolumn{6}{|l|}{ Uredinia } \\
\hline Diameter $(\mu \mathrm{m})$ & $105.0-437.5$ & $132.5-182.5$ & $152.5-175.0$ & $165.0-212.5$ & $105.0-232.5$ \\
\hline Peridia & Hemispherical-irregular & Irregular & Hemispherical & Hemispherical-irregular & Hemispherical \\
\hline Peridial cell color & Hyaline & Hyaline & Hyaline & Hyaline & Hyaline \\
\hline Peridial cell & Irregularly polygonal & Irregularly polygonal & Irregularly polygonal & Irregularly polygonal & Irregularly polygonal \\
\hline Peridial cell diam $(\mu \mathrm{m})$ & $13.5-24.6$ & $14.5-23.5$ & $21.3-25.0$ & $17.5-25.0$ & $12.5-22.5$ \\
\hline \multicolumn{6}{|l|}{ Urediniospores } \\
\hline Size $(\mu \mathrm{m})$ & $16.3-23.8 \times 12.5-17.5$ & $15.0-22.5 \times 11.3-17.5$ & $15.0-20 \times 11.3-15.0$ & $15.0-22.5 \times 12.5-18.8$ & $15.0-20.0 \times 12.5-15.0$ \\
\hline Thickness $(\mu \mathrm{m})$ & $1.0-1.6$ & $1.0-2.0$ & $1.0-1.5$ & $1.0-1.5$ & $1.0-1.7$ \\
\hline Shape & Oblong, globose & Oblong & Oblong, globose & Oblong & Oblong \\
\hline Germ-pore & 3-5 (obscure) & 3-5 (obscure) & 4-6 (obscure) & 4-6 (obscure) & $3-7$ (obscure) \\
\hline Germ-pore distribution & Scattered & Scattered & Scattered & Scattered & Scattered \\
\hline Color & Hyaline & Hyaline & Hyaline & Hyaline & Hyaline \\
\hline Surface structure & Echinulate & Echinulate & Echinulate & Echinulate & Echinulate \\
\hline
\end{tabular}

*) The present fungus

Telia not found in specimens from Indonesia and uredinial morphology was identical with that of the rust genus Pucciniastrum (Hiratsuka 1936, 1958; Cummins and Hiratsuka 2003). Comparative morphology of uredinial stage with specimens (TSH-R4285, TSH-R7203, TSHR12804) and descriptions of Uredo fuchsiae Arthur et Holway (Arthur 1924), Pucciniastrum epilobii Otth. (Cunningham 1931; Wilson and Henderson 1966),
Pucciniastrum pustulatum (Pers.) Diet. (Arthur 1934; Cummins 1962) and Pucciniastrum fuchsiae Hiratsuka, f. (Hiratsuka 1936) showed that morphological characteristics of specimens from Indonesia were similar to those of the above specimens and descriptions (Tables 1 and 2). Therefore, specimens on Fuchsia macrostemma var. globosa from Indonesia were identified as Pucciniastrum epilobii Otth (=P. pustulatum, U. fuchsiae).

Table 2 Comparative morphology of uredinial stages between present fungus and descriptions

\begin{tabular}{|c|c|c|c|c|c|c|}
\hline \multirow[t]{2}{*}{ Description } & \multicolumn{6}{|l|}{ Authors (Year) } \\
\hline & $\begin{array}{l}\text { The present observation } \\
\text { (HBI-Bal 505) }\end{array}$ & $\begin{array}{l}\text { Cunningham } \\
\text { (1931) }\end{array}$ & Arthur (1924) & Arthur (1934) & $\begin{array}{l}\text { Wilson and } \\
\text { Henderson (1966) }\end{array}$ & Hiratsuka (1936) \\
\hline Species & Pucciniastrum epilobii & $\begin{array}{l}\text { Pucciniastrum } \\
\quad \text { epilobii }\end{array}$ & Uredo fuchsiae & $\begin{array}{l}\text { Pucciniastrum } \\
\text { pustulatum }\end{array}$ & $\begin{array}{l}\text { Pucciniastrum } \\
\quad \text { epilobii }\end{array}$ & Pucciniastrum fucshiae \\
\hline \multicolumn{7}{|l|}{ Uredinia } \\
\hline Diamater $(\mu \mathrm{m})$ & $105.0-437.5$ & $100-300$ & $100-200$ & - & $100-250$ & $100-300$ \\
\hline Opening apical pore & Exist & Exist & Exist & - & Exist & Exist \\
\hline Peridia & Hemispherical-irregular & Flattened-globose & Hemispheric & - & Hemispheric & Hemispheric \\
\hline Peridial cell & Irregularly polygonal & - & Rectangular-rhombic & - & $\begin{array}{l}\text { Cubical-smooth } \\
(2 \mu \mathrm{m} \text { thick; } \\
1-18 \mu \mathrm{m} \text { long })\end{array}$ & $\begin{array}{l}\text { Irregularly polygonal } \\
\quad 6-8 \mu \mathrm{m}\end{array}$ \\
\hline \multicolumn{7}{|l|}{ Urediniospores } \\
\hline Size $(\mu \mathrm{m})$ & $16.3-23.8 \times 12.5-17.5$ & $15-24 \times 10-15$ & $18-24 \times 13-16 \times$ & $13-23 \times 10-14$ & $15-23 \times 10-15$ & $14.5-24 \times 10-16.5$ \\
\hline Thickness $(\mu \mathrm{m})$ & $1.0-1.6$ & 1 & $1-2$ & 1 & $1-1.5$ & $1-1.5$ \\
\hline Shape & Oblong, globose & Obovate-polygonal & Ellipsoid & Obovate-oval & Ovoid-ellipsoid & Subglobose, ovate, oblong \\
\hline Germ-pore & $3-5$ (obscure) & 4 (obscure) & Obscure & - & - & $6-9$ \\
\hline Germ-pore distribution & Scattered & Scattered & - & - & - & Scattered \\
\hline Color & Hyaline & Hyaline & Hyaline & Colorless & Hyaline & Hyaline \\
\hline Surface structure & Echinulate & Echinulate & Echinulate & Echinulate (finely) & Echinulate-short & Echinulate (finely) \\
\hline
\end{tabular}

-: no description 


\section{Discussion}

A rust fungus on Fuchsia was first described as Uredo fuchsiae Arthur et Holway in 1918 based on the uredinial stage on Fuchsia splendens Zucc. collected from Guatemala (Arthur 1918, 1934). Hiratsuka $(1927,1936)$ transferred this species to the genus Pucciniastrum as P. fuchsiae Hiratsuka, f. because of its morphological similarity to the uredinial stage of Pucciniastrum though the telial stage was not found. Hiratsuka (1958), and Wilson and Henderson (1966) treated this species as a synonym of Pucciniastrum epilobii Otth because of morphological similarity and cross inoculation experiments conducted by Gäumann in 1942 .

Pucciniastrum epilobii has a wide host range in the Onagraceae and has been confused with Pucciniastrum pustulatum Dietel. Arthur (1934) considered that these two species were synonymous, and treated $P$. pustulatum as its valid name. $P$. epilobii was considered its valid name by many other authors (Cunningham 1931; Hiratsuka 1936, 1958; Gäumann 1959; Wilson and Henderson 1966; Hiratsuka et al. 1992) and has been accepted widely.

Sinclair et al. (1987) reported that $P$. epilobii and $P$. pustulatum are different species and considered $P$. pustulatum is a rust species of Fuchsia. . They treated P. epilobii as a species which is able to infect Epilobium adenocaulon and E. glandulosum and unable to infect E. angustifolium (Sinclair et al. 1987). Gäumann (1959) also reported forma specialis in $P$. epilobii. We consider that the above two species are the same species because of morphological similarity and both infect plant species within the same familiy.

Pucciniastrum epilobii Otth (=P. pustulatum, U. fuchsiae) has been reported from Central-North America (Hiratsuka 1958; Loring and Roth 1964; Strider and Jones 1978; Farr et al. 1989), Europe (Hiratsuka 1958; Gäumann 1959; Wilson and Henderson 1966), and Oceania (McNabb and Laurenson 1965; Dingley 1969; McKenzie 1998), but not from Fuchsia spp. in Asia, though its distribution on Epilobium and other host plants had been reported from Asia. This is the first report of P. epilobii on Fuchsia in Indonesia and also Asia.

Recently, Mikronegeria fuchsiae P.E. Crane et R. S. Peterson (=Uredo fuchsiae (Cooke) Henn, non Arthur et Holway) was reported to produce uredinial and telial stages on Fuchsia excorticata (J.R. Forst et G.) L.f. and F. perscandens Cockayne et Allan from New Zealand (Crane and Peterson 2007). Its spermogonial and aecial stages are produced on Phyllocladus spp. (Crane and Peterson 2007). However, M. fuchsiae is quite different from $P$. epilobii in uredinial and telial morphology. Uredinia of $M$. fuchsiae have no peridium, whereas those of $P$. epilobii have peridia (Fig. 1b, c).

\section{References}

Arthur JC (1918) Uredinales of Guatemala based on collections by E. W. D. Holway. IV. Puccinia on Carduaceae, form-genera and index. Am J Bot 5:522-550

Arthur JC (1924) North American Flora 7:614

Arthur JC (1934) Manual of the rusts in United Stated and Canada. Hafner Publishing Company, New York, p 438

Boedijn KB (1960) The Uredinales of Indonesia. Nova Hedwigia 1:463-495

Crane PE, Peterson RS (2007) Mikronegeria fuchsiae sp. nov., a rust fungus on Fuchsia and Phyllocladus in New Zealand. New Zeal J Bot 45:707-713

Cummins GB (1962) Supplement to Arthur's manual of the rusts in United States and Canada. Hafner Publishing Company, New York, p 24

Cummins GB, Hiratsuka Y (2003) Illustrated genera of rust fungi. APS Press, St. Paul, p 225

Cunningham GH (1931) The rust fungi of New Zealand. John McIndoe, Dunedin, p 261

Dingley JM (1969) Records of plant diseases in New Zealand. Bull New Zeal Depart Sci Ind Res 192:1-298

Farr D, Bills GF, Chamuris GP, Rossman AY (1989) Fungi on plants and plant products in the United States. The American Phytopathology Society, St. Paul, p 575

Gäumann E (1959) Die Rostpilze Mitteleuropas. Buchdruckerei Büchler \& Co., Bern, p 1407

Hiratsuka N (1927) Beitrage zu einer Monographie der Gattung Pucciniastrum Otth. Journal of the Faculty of Agriculture Hokkaido Imperial University 21:63-120

Hiratsuka N (1936) A monograph of the Pucciniastraceae. Memoirs of the Tottori Agricultural College 4:1-374

Hiratsuka N (1958) Revision of taxonomy of the Pucciniastreae with special reference to species of the Japanese archipelago. KASAI Publishing and Printing Co., Tokyo, p 167

Hiratsuka N, Sato S, Katsuya K, Kakishima M, Hiratsuka Y, Kaneko S, Ono Y, Sato T, Harada Y, Hiratsuka T, Nakayama K (1992) Rust flora of Japan. Tsukuba Shuppankai, Tsukuba, p 1205

Jennings DM, Ford-Lloyd BV, Butler GM (1989) An aniline-blue squash technique for observation of urediniospore germ pore. Mycol Res 92:230-251

Loring LB, Roth LF (1964) Pucciniastrum epilobii on Fuchsia in Oregon. Plant Dis Rep 48:99

McKenzie EHC (1998) Rust fungi of New Zealand- an introduction, and list of recorded species. New Zeal J Bot 36:233-271

McNabb RFR, Laurenson JB (1965) A rust of cultivated fuchsias. New Zeal J Agr Res 8:336-339

Semangun H (1992) Host index of plant diseases in Indonesia. Gadjah Mada University Press, Yogyakarta, p 351

Sinclair WA, Lyon HH, Johnson WT (1987) Diseases of tree and shrubs. Comstock Publishing Associates, Cornell University Press. 575 pp

Strider DL, Jones RK (1978) Rust of Fuchsia in North Carolina. Plant Dis Rep 62:745-746

Wilson M, Henderson DM (1966) British rust fungi. Cambridge University Press, London, p 384 